ASTHMA

\title{
Fruit and vegetable intakes and asthma in the E3N study
}

\author{
I Romieu, R Varraso, V Avenel, B Leynaert, F Kauffmann, F Clavel-Chapelon

Correspondence to: Dr I Romieu, Instituto Nacional de Salud

Publica, Av. Universidad \# 655, Col Santa Maria Ahuacatitlan, 62508 Cuernavaca, Morelos, Mexico; iromieu@correo. insp.mx

Received

14 December 2004

Accepted

21 November 2005

Published Online First

5 January 2006
Background: A study was undertaken to investigate whether dietary intake predicted the prevalence of adult asthma among French women participating in the E3N study.

Methods: Of 68535 women who completed a food frequency questionnaire in 1993 which included 238 food items, $2145(3.1 \%)$ reported having asthma. The distribution of food intake was divided into quartiles $\left(Q_{1}-Q_{4}\right)$ and the prevalence of asthma was compared between the different quartiles (lowest as reference) using logistic regression models on cross sectional data.

Results: After adjusting for age, body mass index, menopausal status, smoking status, total caloric intake, physical activity, and use of dietary supplements, women who had a greater intake of tomatoes $\left(\mathrm{OR}_{\mathrm{Q} 1-\mathrm{Q} 4}\right.$ $0.8595 \% \mathrm{Cl} 0.75$ to 0.96 , test for trend $p=0.02)$, carrots $\left(O R_{Q 1-Q 4} 0.8195 \% \mathrm{Cl} 0.72\right.$ to 0.92 , test for trend $p=0.0003)$, and leafy vegetables $\left(O R_{Q 1-Q 4} 0.8295 \% \mathrm{Cl} 0.73\right.$ to 0.93 , test for trend $\left.p=0.0009\right)$ had a lower prevalence of asthma. Apples were marginally related to the prevalence of asthma. No other fruits or vegetables were significantly associated with asthma prevalence.

Conclusions: These results suggest that the intake of some vegetables may decrease the prevalence of adult asthma.
$\mathrm{E}$ nvironmental factors appear to be critical for the increase in the prevalence of asthma recently observed in most developed countries. Changes in diet such as decreased consumption of fresh fruit and vegetables might have a major role. ${ }^{1-3}$ However, the epidemiological evidence for the role of food intake in the prevalence of asthma among adults is still scarce. Previous studies have reported that a greater intake of fresh fruit is related to a lower prevalence of respiratory symptoms ${ }^{4}$ and to a lower incidence of nonspecific lung diseases, ${ }^{5}$ but no specific foods were identified. Although vitamin $\mathrm{C}$ is believed to be the principal candidate for the apparent benefit of plant foods, ${ }^{6}$ a prospective study ${ }^{7}$ found no beneficial effect of dietary vitamin $C$ intake and intervention trials provided conflicting results. ${ }^{8}$ Antioxidants other than the vitamin $\mathrm{C}$ contained in fruit and vegetables might play an important role in asthma. In a recent casecontrol study, Shaheen $\mathrm{et}^{\mathrm{al}} \mathrm{l}^{9}$ reported that the consumption of apples and red wine were negatively related to asthma, suggesting the beneficial effect of flavonoids.

There are a number of reasons for exploring the effects of fruit and vegetables rather than individual nutrients. Food contains several substances and an analysis focusing on nutrients might miss important components and interactions between nutrients. Also, people eat food and not nutrients, so foods are easier to convert into dietary recommendation. For these reasons, public health programmes have focused on the promotion of consumption of fruit and vegetables. ${ }^{10}$ Although this recommendation was mostly based on results from cancer research, it appears that the consumption of fruit and vegetables might also be beneficial for lung health. It is therefore important to determine which fruit and vegetables are most beneficial for asthma prevention. We used data from the E3N (Etude Epidémiologique auprès des femmes de la MGEN) study, the French branch of the European Prospective Investigation into Cancer and Nutrition (EPIC), to evaluate the association of fruit and vegetable intake with asthma prevalence in a large population of adult women.

\section{METHODS}

\section{Study population}

The E3N study is a prospective investigation of major chronic diseases among a cohort of members from the Mutuelle Générale de l'Education Nationale (MGEN), a national health insurance plan covering mostly teachers. The general characteristics of this population have been reported elsewhere. ${ }^{11}$ This study began in 1990 when a baseline questionnaire $\left(Q_{1}\right)$ was sent to 103089 women aged 4065 years. A follow up questionnaire was sent in January 1992 $\left(\mathrm{Q}_{2}\right)$ and approximately every 2 years thereafter. In June 1993, in addition to the follow up questionnaire, a dietary assessment was conducted using a dietary history questionnaire $\left(Q_{3}\right)$ to which 75518 women responded.

Our study population was composed of 68535 women who answered $Q_{1}, Q_{2}$ and $Q_{3}$ and met the inclusion criteria for the analysis (fig 1). Reasons for exclusion were: no answer to the previous questionnaire $\left(\mathrm{Q}_{2}\right)(\mathrm{n}=4424)$; unrealistic figures reported to the food questionnaire $\left(\mathrm{Q}_{3}\right)$ based on the ratio of energy intake/energy requirement (based on the EPIC methodology $\left.{ }^{11}\right)(\mathrm{n}=1294)$; asthma diagnosis during childhood or no specified date for asthma diagnosis $(n=1265)$. In order to study a homogeneous group of asthmatics, analyses were restricted to those who reported adult onset asthma. One important reason for this choice is that longitudinal studies performed in cohorts from childhood to adulthood and during adulthood have shown a low tracking of dietary habits from childhood to adulthood, ${ }^{12}$ while tracking of diet in adulthood is acceptable. ${ }^{13}$

The final participation rate was 68 5335/98 997 (69.2\%). Data were analysed cross sectionally to evaluate the association between fruit and vegetable intake and asthma prevalence.

\section{Definition of a prevalent case of asthma}

Our definition of asthma was based on the presence of an affirmative answer to the questions "Did you have an asthma 


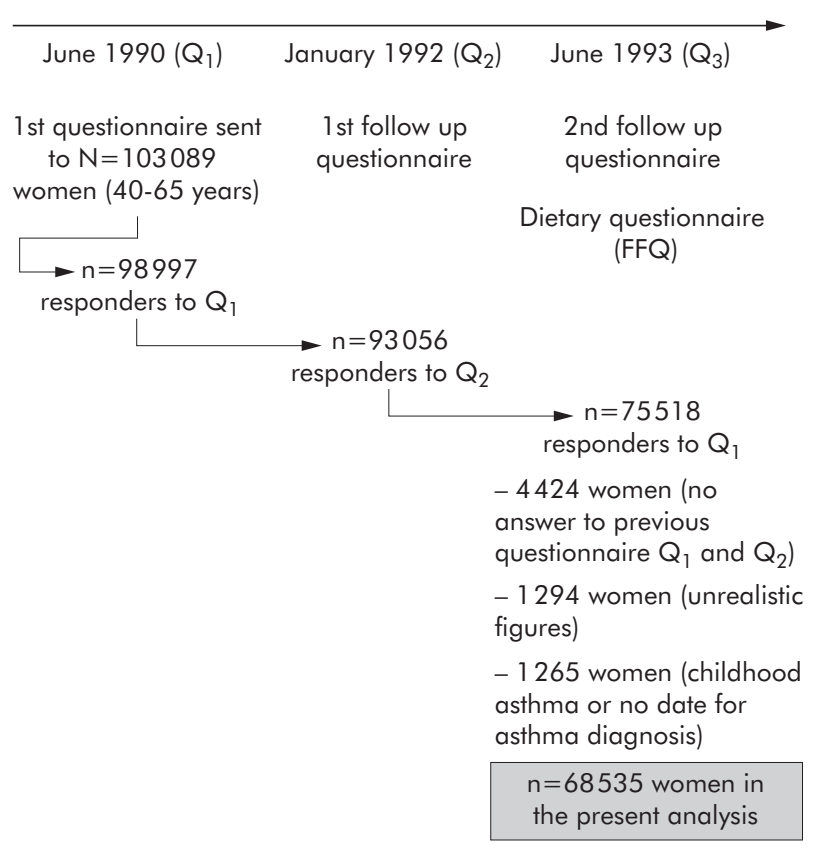

Figure 1 Design of the study.

attack?" and "Age at time of the first attack" on the second follow up questionnaire $\left(\mathrm{Q}_{3}\right)$. Among the 68535 volunteers we identified 2145 women with asthma who reported having the first attack in adulthood and provided the age when they had been diagnosed. These were included in the analysis.

Our classification of asthma was further validated using information gathered in the follow up questionnaire sent in $2003\left(\mathrm{Q}_{7}\right)$. Asthma was defined by questions based on the ATS questionnaire: ${ }^{14}$ "Have you ever had asthma attacks" and, if yes, "Was this diagnosis confirmed by a doctor ?" Of the 68535 women included in the present analysis, 62849 provided information on asthma in $2003\left(\mathrm{Q}_{7}\right) ; 725$ women who reported incident asthma between $\mathrm{Q}_{3}$ and $\mathrm{Q}_{7}$ and 374 who reported asthma in childhood in $\mathrm{Q}_{7}$ were excluded. Based on the 61750 women with both information at $\mathrm{Q}_{3}$ and $\mathrm{Q}_{7}$, the agreement between the asthma definition used in the present analysis $\left(\mathrm{Q}_{3}\right)$ and asthma assessed in $\mathrm{Q}_{7}$ was very strong. Overall, 1661 women $(2.7 \%)$ were defined as asthmatics in $\mathrm{Q}_{3}$ and 1909 (3.1\%) in $\mathrm{Q}_{7}$. Most of the women who reported asthma in $\mathrm{Q}_{3}$ were classified as asthmatics in $\mathrm{Q}_{7}$. The agreement between the asthma definition used in the present analysis $\left(Q_{3}\right)$ and asthma assessed in $\mathrm{Q}_{7}$ (ATS definition) was strong (kappa statistic $0.77)$, and the definition of asthma at $\mathrm{Q}_{3}$ had a high sensitivity $(72.3 \%)$ and specificity (99.4\%) using asthma assessed in $\mathrm{Q}_{7}$ as the gold standard.

\section{Food frequency questionnaire}

The dietary questionnaire sent to participants in 1993 was composed of two parts with a booklet of photographs to facilitate the estimation of portion sizes. The first part included questions on the consumption (frequency and quantity) of 66 food groups. The second part included qualitative questions. Overall, the questionnaire provided an estimate for daily consumption of 208 food items. Both the questionnaire and the illustrated booklet had been validated previously. ${ }^{15}{ }^{16}$ We considered the food classification proposed by EPIC. ${ }^{17}$ Total calorie intake was estimated using the food frequency questionnaire and expressed in kcal/day.

\section{Body mass index}

Body mass index (BMI) was calculated based on the height and weight reported in the questionnaire administered at baseline. BMI was used as a continuous and categorical variable.

\section{Other information}

We used information provided on the 1993 questionnaire $\left(\mathrm{Q}_{3}\right)$. Tobacco consumption was categorised as never, past, and current smoker. Current exercise and energy expenditure were calculated by multiplying the duration of daily activities and leisure physical activities. Estimated metabolic energy spent was based on the values proposed by James and Schofield ${ }^{18}$ and categorised into quartiles of physical activity. Women were classified as premenopausal, postmenopausal or perimenopausal. Because our population was composed mostly of teachers from the MGEN, years of education were used as a proxy of socioeconomic status. The presence of allergy was classified as either present or absent.

\section{Statistical analysis}

The general characteristics of the asthmatic and control women were compared using the $\chi^{2}$ test statistics for categorical data. ${ }^{19}$ Fruit and vegetable intake of the two groups of women were compared after log transformation of the data to normalise the distribution using $t$ test statistics. ${ }^{19}$ The association between asthma in adulthood and fruit and vegetable intake was studied using logistic regression models,${ }^{20}$ adjusting for potential confounding factors including age, total calorie intake, BMI, physical activity, smoking status, menopausal status, ${ }^{21-23}$ and the use of dietary supplements. Because our population came from a fairly homogenous socioeconomic status, adjusting for this variable (years of education) did not modify our estimates. Fruit and vegetable intake was categorised into quartiles based on the distribution among control women. The odds ratios (OR) were determined by comparison with the lowest quartiles. Correction for multiple comparisons was performed by the Bonferroni method. ${ }^{24}$ The significance of the interaction between smoking status and fruit and vegetable intake was tested. Although the interaction terms were not significant, we further stratified our analysis by smoking status (never smoker, ex-smoker or current smoker) to determine if there was some indication of a modifying effect by this variable. We tested for linear trends in ORs with increasing exposure using the likelihood ratio test. ${ }^{25}$ All analyses were conducted using SAS Version 8.

\section{RESULTS}

Of the 68535 women included in the analysis, 2145 (3.1\%) reported having had an asthma attack in adulthood before application of the food frequency questionnaire in 1993. The characteristics of the women included and excluded from the analysis were similar with regard to age, smoking status, menopausal status, physical activity, socioeconomic status, and use of dietary supplements, but women excluded were more likely to have a lower mean (SD) BMI $\left(22.9(3.3) \mathrm{kg} / \mathrm{m}^{2}\right.$ $v 23.3(3.8) \mathrm{kg} / \mathrm{m}^{2}, \mathrm{p}<0.0001$ ), to have a higher mean (SD) total calorie intake (2345.1 (1537.3) kcal/day $v 2141.4$ $(566.0) \mathrm{kcal} /$ day, $\mathrm{p}<0.0001)$, and to report allergy $(45.5 \% \mathrm{v}$ $23 \%, \mathrm{p}<0.0001$ ).

The characteristics of the study population are shown in table 1 according to asthma status. Women who suffered from asthma had a larger BMI, smoked less, and reported more frequent use of dietary supplements and allergy than women who did not have asthma.

Table 2 presents the dietary intake of specific fruits and vegetables among prevalent cases of asthma and control women. Caloric intake was higher among women reporting asthma. No significant difference in food intake was observed. 


\begin{tabular}{|c|c|c|c|}
\hline & $\begin{array}{l}\text { Asthmatic women } \\
(\mathrm{n}=2145)\end{array}$ & $\begin{array}{l}\text { Control women } \\
(n=66390)\end{array}$ & p value ${ }^{*}$ \\
\hline \multicolumn{4}{|l|}{ Age (years) } \\
\hline$<48$ & $30.6 \%$ & $31.6 \%$ & \\
\hline $48-53$ & $24.5 \%$ & $24.4 \%$ & \\
\hline $53-58$ & $20.9 \%$ & $20.2 \%$ & 0.8 \\
\hline $58-63$ & $13.6 \%$ & $13.8 \%$ & \\
\hline$>63$ & $10.4 \%$ & $10.0 \%$ & \\
\hline \multicolumn{4}{|l|}{ Physical activity } \\
\hline $1^{\text {st }}$ quartile & $26.1 \%$ & $25.7 \%$ & \\
\hline $2^{\text {nd }}$ quartile & $22.7 \%$ & $25.3 \%$ & \\
\hline $3^{\text {rd }}$ quartile & $24.8 \%$ & $24.2 \%$ & 0.04 \\
\hline $4^{\text {th }}$ quartile & $26.4 \%$ & $24.8 \%$ & \\
\hline \multicolumn{4}{|l|}{ Caloric intake (kcal/day) } \\
\hline $1^{\text {st }}$ quartile $(<1737)$ & $24.2 \%$ & $24.5 \%$ & \\
\hline $2^{\text {nd }}$ quartile (1737-2088) & $24.2 \%$ & $25.5 \%$ & \\
\hline $3^{\text {rd }}$ quartile (2088-2490) & $25.4 \%$ & $25.5 \%$ & 0.2 \\
\hline \multirow{2}{*}{\multicolumn{4}{|c|}{ Body mass index $\left(\mathrm{kg} / \mathrm{m}^{2}\right)$}} \\
\hline & & & \\
\hline$<20$ & $12.8 \%$ & $15.5 \%$ & \\
\hline $20-25$ & $60.9 \%$ & $64.3 \%$ & 0.0001 \\
\hline $25-30$ & $20.2 \%$ & $16.6 \%$ & \\
\hline$>30$ & $6.1 \%$ & $3.6 \%$ & \\
\hline \multicolumn{4}{|l|}{ Tobacco consumption } \\
\hline Never smokers & $61.4 \%$ & $64.7 \%$ & \\
\hline Ex-smokers & $27.8 \%$ & $22.6 \%$ & 0.0001 \\
\hline Current smokers & $10.8 \%$ & $12.7 \%$ & \\
\hline \multicolumn{4}{|l|}{ Menopausal status } \\
\hline Premenopausal & $12.0 \%$ & $12.0 \%$ & \\
\hline Postmenopausal & $79.6 \%$ & $79.8 \%$ & 0.9 \\
\hline Perimenopausal & $8.4 \%$ & $8.2 \%$ & \\
\hline \multicolumn{4}{|c|}{ Education/number of years at school } \\
\hline$<12$ & $0.5 \%$ & $0.5 \%$ & \\
\hline 12 & $11.0 \%$ & $11.4 \%$ & \\
\hline 14 & $49.1 \%$ & $51.2 \%$ & 0.3 \\
\hline 16 & $20.4 \%$ & $19.0 \%$ & \\
\hline 17 & $19.0 \%$ & $17.9 \%$ & \\
\hline Vitamin supplementation use & $25.0 \%$ & $21.1 \%$ & 0.0001 \\
\hline Allergy & $76.4 \%$ & $21.3 \%$ & 0.0001 \\
\hline
\end{tabular}

Table 3 shows the associations between quartiles of fruit and vegetable intake and asthma in adulthood. After adjusting for BMI, physical activity, menopausal status, smoking, and use of dietary supplements, a decreasing trend in asthma prevalence was observed with increasing intake of apples $\left(\mathrm{OR}_{\mathrm{Q} 1-\mathrm{Q} 4} 0.90,95 \%\right.$ CI 0.80 to 1.02 , test for trend $\mathrm{p}=0.03$ ). Other fruit intake (fruits, citrus fruits, fruits rich in $\beta$-carotene) was not related to the prevalence of asthma.
Leafy vegetable intake was inversely related to asthma prevalence with a significant decreasing trend when intake was increased. Women in the highest quartile of leafy vegetable intake (>90.0 g/day) had a $22.0 \%$ lower risk of reporting asthma than those in the lowest quartile $(\leqslant 39.3 \mathrm{~g} /$ day) (OR $0.82 \quad(95 \%$ CI 0.73 to 0.93$)$, test for trend $\mathrm{p}=0.0009$ ). Intake of fruity vegetables was inversely associated with asthma (test for trend $\mathrm{p}=0.01$ ); women in

\begin{tabular}{|c|c|c|c|}
\hline & $\begin{array}{l}\text { Asthmatic women } \\
(n=2145)\end{array}$ & $\begin{array}{l}\text { Control women } \\
(n=66390)\end{array}$ & p value* \\
\hline $\begin{array}{l}\text { Total caloric intake } \\
\text { Vegetablest }\end{array}$ & $2167.70(585.27)$ & $2140.50(565.39)$ & 0.03 \\
\hline \multicolumn{4}{|l|}{ Vegetables $\dagger$} \\
\hline Fruity vegetables & 69.09 (59.52) & $69.81(56.61)$ & 0.6 \\
\hline Root vegetables & $29.42(26.01)$ & $30.00(25.29)$ & 0.3 \\
\hline Cabbages & $22.75(23.48)$ & $22.70(22.86)$ & 0.9 \\
\hline Tomatoes & $19.41(16.49)$ & $19.48(15.65)$ & 0.8 \\
\hline Carrots & $16.21(15.06)$ & 16.75 (14.85) & 0.09 \\
\hline \multicolumn{4}{|l|}{ Fruits $†$} \\
\hline Fruits & $265.05(175.82)$ & $260.36(167.30)$ & 0.2 \\
\hline Fruits with citric & $48.21(52.33)$ & $48.61(50.03)$ & 0.7 \\
\hline Fruits with $\beta$ carotene & $47.22(47.73)$ & $47.65(46.46)$ & 0.7 \\
\hline Nuts and seeds & $5.46(8.09)$ & $5.49(8.38)$ & 0.9 \\
\hline Apples & $20.11(23.29)$ & $20.81(22.65)$ & 0.15 \\
\hline
\end{tabular}

*p value from $t$ test conducted on log transformed data.

†Food groups: leafy vegetables (chicory, lettuce and spinach), fruity vegetables (artichoke, avocado, tomatoes, cucumber, green beans, eggplants, bell pepper, and zucchini), root vegetables (carrots, radish, beetroot, celeriac, and salsify), fruit (orange, grapefruit, mandarin, apple, pear, banana, kiwi, pineapple, strawberries or raspberries, cherry, peach, melon, apricot, raisins, plums, other fruits), and nuts and seeds. 
Table 3 Association of fruit and vegetable intake and asthma prevalence in adulthood

\begin{tabular}{|c|c|c|c|c|c|}
\hline \multirow[b]{2}{*}{ Food groups and foods $†$} & \multicolumn{4}{|c|}{ Quartile of intake (g/day) } & \multirow{2}{*}{$\begin{array}{l}p \text { test for } \\
\text { trend }\end{array}$} \\
\hline & $Q_{1}$ & $Q_{2}$ & $\mathbf{Q}_{3}$ & $\mathbf{Q}_{4}$ & \\
\hline Fruit & $\leqslant 145.3$ & $>145.3-235.4$ & $>235.4-333.6$ & $>333.6$ & \\
\hline Cases (n) & 543 & 522 & 515 & 565 & \\
\hline Controls (n) & 16339 & 16700 & 16789 & 16562 & \\
\hline Age adjusted OR $(95 \% \mathrm{Cl})$ & 1.00 & $0.94(0.83$ to 1.06$)$ & $0.92(0.81$ to 1.04$)$ & $1.02(0.90$ to 1.15$)$ & 0.8 \\
\hline Multivariate OR $(95 \% \mathrm{Cl})^{*}$ & 1.00 & $0.93(0.82$ to 1.05$)$ & $0.91(0.81$ to 1.03$)$ & $0.98(0.87$ to 1.11$)$ & 0.7 \\
\hline Citrus fruits & $\leqslant 1.2$ & $>1.2-38.4$ & $>38.4-73.3$ & $>73.3$ & \\
\hline Cases (n) & 556 & 538 & 511 & 540 & \\
\hline Controls ( $\mathrm{n}$ ) & 16375 & 16606 & 16745 & 16664 & \\
\hline Age adjusted OR (95\% CI) & 1.00 & $0.96(0.85$ to 1.08$)$ & 0.90 (0.80 to 1.02$)$ & 0.95 (0.84 to 1.07$)$ & 0.3 \\
\hline Multivariate OR $(95 \% \mathrm{Cl})^{*}$ & 1.00 & $0.97(0.86$ to 1.10$)$ & 0.90 (0.80 to 1.02$)$ & 0.94 (0.83 to 1.06$)$ & 0.2 \\
\hline Fruits rich in $\beta$-carotene & $\leqslant 2.6$ & $>2.6-40.1$ & $>40.1-72.1$ & $>72.1$ & \\
\hline Cases (n) & 556 & 534 & 523 & 532 & \\
\hline Controls (n) & 16373 & 16617 & 16848 & 16552 & \\
\hline Age adjusted OR (95\% Cl) & 1.00 & 0.95 (0.84 to 1.07$)$ & 0.91 (0.81 to 1.03$)$ & 0.94 (0.84 to 1.07$)$ & 0.3 \\
\hline Multivariate OR $(95 \% \mathrm{CI})^{*}$ & 1.00 & 0.96 (0.85 to 1.08$)$ & $0.92(0.81$ to 1.04$)$ & 0.94 (0.83 to 1.06$)$ & 0.2 \\
\hline Apple & 0 & $>0-16.2$ & $>16.2-31.2$ & $>31.2$ & \\
\hline Cases (n) & 572 & 560 & 498 & 515 & \\
\hline Controls (n) & 16969 & 16305 & 16452 & 16664 & \\
\hline Age adjusted OR (95\% Cl) & 1.00 & $1.02(0.91$ to 1.15$)$ & $0.90(0.80$ to 1.02$)$ & 0.91 (0.81 to 1.03$)$ & 0.04 \\
\hline Multivariate OR $(95 \% \mathrm{Cl})^{*}$ & 1.00 & $1.04(0.92$ to 1.17$)$ & 0.90 (0.80 to 1.02$)$ & $0.90(0.80$ to 1.02$)$ & 0.03 \\
\hline Nuts and seeds & 0 & $>0-2.9$ & $>2.9-31.2$ & $>31.2$ & \\
\hline Cases (n) & 631 & 507 & 461 & 546 & \\
\hline Controls (n) & 18776 & 15891 & 15080 & 16643 & \\
\hline Age adjusted OR (95\% Cl) & 1.00 & 0.95 (0.85 to 1.07$)$ & 0.91 (0.81 to 1.03$)$ & $0.98(0.87$ to 1.11$)$ & 0.6 \\
\hline Multivariate OR $(95 \% \mathrm{Cl})^{*}$ & 1.00 & 0.95 (0.85 to 1.07$)$ & $0.90(0.79$ to 1.01$)$ & 0.93 (0.82 to 1.05$)$ & 0.16 \\
\hline Leafy vegetables & $\leqslant 39.3$ & $>39.3-62.9$ & $>62.9-90.0$ & $>90.0$ & \\
\hline Cases (n) & 572 & 542 & 516 & 515 & \\
\hline Controls (n) & 16335 & 16694 & 16797 & 16564 & \\
\hline Age adjusted OR (95\% Cl) & 1.00 & $0.93(0.82$ to 1.05$)$ & $0.88(0.78$ to 0.99$)$ & $0.89(0.79$ to 1.00$)$ & 0.03 \\
\hline Multivariate OR $(95 \% \mathrm{Cl})^{*}$ & 1.00 & $0.91(0.81$ to 1.02$)$ & $0.85(0.75$ to 0.95$)$ & $0.82(0.73$ to 0.93$)$ & 0.0009 \\
\hline Fruity vegetables & $\leqslant 24.9$ & $>24.9-64.8$ & $>64.8-101.6$ & $>101.6$ & \\
\hline Cases (n) & 578 & 529 & 501 & 537 & \\
\hline Controls (n) & 16316 & 16711 & 16747 & 16616 & \\
\hline Age adjusted OR (95\% Cl) & 1.00 & 0.89 (0.79 to 1.01$)$ & $0.85(0.75$ to 0.95$)$ & 0.91 (0.81 to 1.03 ) & 0.08 \\
\hline Multivariate OR $(95 \% \mathrm{Cl})^{*}$ & 1.00 & $0.92(0.81$ to 1.04$)$ & $0.84(0.74$ to 0.95$)$ & $0.87(0.77$ to 0.99$)$ & 0.01 \\
\hline Tomatoes & $\leqslant 6.4$ & $>6.4-17.9$ & $>17.9-28.2$ & $>28.2$ & \\
\hline Cases (n) & 570 & 516 & 546 & 513 & \\
\hline Controls (n) & 16357 & 16689 & 16719 & 16625 & \\
\hline Age adjusted OR (95\% Cl) & 1.00 & 0.90 (0.79 to 1.00$)$ & $0.94(0.83$ to 1.06$)$ & $0.89(0.79$ to 1.00$)$ & 0.11 \\
\hline Multivariate OR $(95 \% \mathrm{Cl})^{*}$ & 1.00 & 0.91 (0.80 to 1.02$)$ & $0.93(0.83$ to 1.05$)$ & 0.85 (0.75 to 0.96$)$ & 0.02 \\
\hline Root vegetables & $\leqslant 8.6$ & $>8.6-27.5$ & $>27.5-44.6$ & $>44.6$ & \\
\hline Cases (n) & 571 & 552 & 498 & 524 & \\
\hline Controls (n) & 16331 & 16673 & 16757 & 16629 & \\
\hline Age adjusted OR (95\% Cl) & 1.00 & 0.95 (0.84 to 1.07$)$ & $0.85(0.75$ to 0.96$)$ & $0.90(0.80$ to 1.02$)$ & 0.03 \\
\hline Multivariate OR $(95 \% \mathrm{Cl})^{*}$ & 1.00 & 0.97 (0.86 to 1.09 ) & 0.85 (0.75 to 0.96$)$ & $0.86(0.77$ to 0.98$)$ & 0.004 \\
\hline Carrots & $\leqslant 3.8$ & $>3.8-14.9$ & $>14.9-24.9$ & $>24.9$ & \\
\hline Cases (n) & 576 & 557 & 517 & 495 & \\
\hline Controls (n) & 16313 & 16710 & 16698 & 16669 & \\
\hline Age adjusted OR $(95 \% \mathrm{Cl})$ & 1.00 & $0.95(0.84$ to 1.06$)$ & $0.88(0.78$ to 0.99$)$ & $0.84(0.74$ to 0.95$)$ & 0.002 \\
\hline Multivariate OR $(95 \% \mathrm{Cl})^{*}$ & 1.00 & 0.97 (0.86 to 1.09 ) & $0.86(0.78$ to 0.99$)$ & $0.81(0.72$ to 0.92$)$ & 0.0003 \\
\hline Cabbage & $\leqslant 1.3$ & $>1.3-18.1$ & $>18.1-34.8$ & $>34.8$ & \\
\hline Cases (n) & 568 & 520 & 505 & 552 & \\
\hline Controls (n) & 16358 & 16653 & 16705 & 16674 & \\
\hline Age adjusted OR (95\% Cl) & 1.00 & $0.90(0.80$ to 1.02$)$ & $0.87(0.77$ to 0.98$)$ & $0.95(0.85$ to 1.07$)$ & 0.3 \\
\hline Multivariate OR $(95 \% \mathrm{Cl})^{*}$ & 1.00 & $0.93(0.82$ to 1.05$)$ & $0.87(0.77$ to 0.98$)$ & $0.91(0.81$ to 1.03$)$ & 0.07 \\
\hline
\end{tabular}

*Adjusted for age, total caloric intake, BMI, physical activity, smoking status, menopausal status, and vitamin supplementation use.

†Food groups: leafy vegetables (chicory, lettuce and spinach), fruity vegetables (artichoke, avocado, tomatoes, cucumber, green beans, eggplants, bell pepper, and zucchini), root vegetables (carrots, radish, beetroot, celeriac, and salsify), fruit (orange, grapefruit, mandarin, apple, pear, banana, kiwi, pineapple, strawberries or raspberries, cherry, peach, melon, apricot, raisins, plums, other fruits) and nuts and seeds.

the highest quartile of tomato intake ( $>28.2 \mathrm{~g} / \mathrm{day})$ had a $17.6 \%$ lower risk of having asthma than those in the lowest quartile ( $\leqslant 6.4 \mathrm{~g}$ /day) $\left(\mathrm{OR}_{\mathrm{Q} 1-\mathrm{Q} 4} 0.85\right.$ (95\% CI 0.75 to 0.96$)$, test for trend $p=0.02$ ). Increased intake of root vegetables was also inversely related to asthma prevalence (test for trend $\mathrm{p}=0.004)$. Women in the highest quartile of carrot intake $(>24.9 \mathrm{~g} /$ day) had a $20.0 \%$ decrease in the risk of having asthma $\left(\mathrm{OR}_{\mathrm{Ql}-\mathrm{Q} 4} 0.81\right.$ (95\% CI 0.72 to 0.92$)$, test for trend $\mathrm{p}=0.0003$ ) compared with those with low carrot intake $(\leqslant 3.8 \mathrm{~g} /$ day $)$. No significant association was observed with cabbage intake. Similar results were found in multi-food models including leafy vegetables and tomatoes or leafy vegetables and carrots and the potential confounding factors previously mentioned, which suggests that intake of leafy vegetables, tomatoes and carrots may independently play a beneficial role on the prevalence of asthma.

Twenty six foods were studied: leafy vegetables, chicory, lettuce, spinach, fruity vegetables, artichoke, avocado, tomatoes, cucumber, green beans, eggplants, bell pepper, zucchini, root vegetables, carrots, radish, beetroot, celeriac, salsify, fruits, fruits with citrus, fruits with $\beta$-carotene, nuts and seeds, apples, blue fish, and other fish. The Bonferroni correction was therefore applied by multiplying by 26 the $p$ value presented in the tables. Two of the three main 
Table 4 Association of leafy vegetables, tomatoes and carrots with asthma prevalence in adulthood according to smoking status

\begin{tabular}{|c|c|c|c|c|c|}
\hline \multirow[b]{2}{*}{ Food groups or foodst } & \multicolumn{4}{|c|}{ Quartile of intake (g/day) } & \multirow{2}{*}{$\begin{array}{l}p \text { test for } \\
\text { trend }\end{array}$} \\
\hline & $Q_{1}$ & $Q_{2}$ & $\mathbf{Q}_{3}$ & $\mathbf{Q}_{4}$ & \\
\hline Leafy vegetables & $\leqslant 39.3$ & $>39.3-62.9$ & $>62.9-90.0$ & $>90.0$ & \\
\hline \multicolumn{6}{|l|}{ Non-smokers } \\
\hline Cases (n) & 342 & 324 & 312 & 313 & \\
\hline Controls (n) & 10369 & 10693 & 10781 & 10249 & \\
\hline Age adjusted OR $(95 \% \mathrm{Cl})$ & 1.00 & 0.92 (0.79 to 1.07$)$ & $0.88(0.75$ to 1.03$)$ & $0.93(0.79$ to 1.08$)$ & 0.2 \\
\hline Multivariate OR $(95 \% \mathrm{Cl})^{*}$ & 1.00 & 0.90 (0.77 to 1.05$)$ & 0.85 (0.72 to 0.99$)$ & $0.86(0.74$ to 1.01$)$ & 0.04 \\
\hline \multicolumn{6}{|l|}{ Ex-smokers } \\
\hline Cases (n) & 148 & 155 & 137 & 144 & \\
\hline Controls (n) & 3409 & 3636 & 3715 & 3948 & \\
\hline Age adjusted OR (95\% CI) & 1.00 & $0.98(0.78$ to 1.24$)$ & 0.85 (0.67 to 1.07$)$ & $0.83(0.66$ to 1.05$)$ & 0.06 \\
\hline Multivariate OR $(95 \% \mathrm{Cl})^{*}$ & 1.00 & 0.97 (0.77 to 1.22$)$ & 0.82 (0.65 to 1.05 ) & $0.78(0.61$ to 0.99$)$ & 0.01 \\
\hline \multicolumn{6}{|l|}{ Current smokers } \\
\hline Cases (n) & 73 & 52 & 57 & 47 & \\
\hline Controls (n) & 2246 & 2042 & 1977 & 2018 & \\
\hline Age adjusted OR (95\% Cl) & 1.00 & $0.78(0.54$ to 1.12$)$ & $0.89(0.62$ to 1.26$)$ & 0.72 (0.49 to 1.04$)$ & 0.13 \\
\hline Multivariate OR $(95 \% \mathrm{Cl})^{*}$ & 1.00 & 0.78 (0.54 to 1.11$)$ & $0.88(0.62$ to 1.25$)$ & $0.69(0.47$ to 1.00$)$ & 0.10 \\
\hline Tomatoes & $\leqslant 6.4$ & $>6.4-17.9$ & $>17.9-28.2$ & $>28.2$ & \\
\hline \multicolumn{6}{|l|}{ Non-smokers } \\
\hline Cases (n) & 327 & 322 & 336 & 306 & \\
\hline Controls (n) & 10253 & 10752 & 10631 & 10456 & \\
\hline Age adjusted OR $(95 \% \mathrm{Cl})$ & 1.00 & $0.94(0.80$ to 1.10$)$ & $0.99(0.85$ to 1.16$)$ & $0.92(0.78$ to 1.07$)$ & 0.4 \\
\hline Multivariate OR $(95 \% \mathrm{Cl})^{*}$ & 1.00 & $0.96(0.82$ to 1.12$)$ & $0.98(0.85$ to 1.16$)$ & $0.88(0.75$ to 1.03$)$ & 0.17 \\
\hline \multicolumn{6}{|l|}{ Ex-smokers } \\
\hline Cases (n) & 154 & 132 & 154 & 144 & \\
\hline Controls (n) & 3540 & 3558 & 3798 & 3812 & \\
\hline Age adjusted OR $(95 \% \mathrm{Cl})$ & 1.00 & 0.86 (0.68 to 1.09$)$ & $0.94(0.75$ to 1.18$)$ & $0.88(0.69$ to 1.10$)$ & 0.4 \\
\hline Multivariate OR $(95 \% \mathrm{Cl})^{*}$ & 1.00 & $0.88(0.69$ to 1.11$)$ & $0.95(0.75$ to 1.19$)$ & 0.85 (0.67 to 1.07$)$ & 0.2 \\
\hline \multicolumn{6}{|l|}{ Current smokers } \\
\hline Cases (n) & 79 & 52 & 44 & 54 & \\
\hline Controls (n) & 2232 & 2054 & 1982 & 2015 & \\
\hline Age adjusted OR $(95 \% \mathrm{Cl})$ & 1.00 & $0.72(0.50$ to 1.02$)$ & $0.63(0.43$ to 0.91$)$ & $0.75(0.53$ to 1.07$)$ & 0.07 \\
\hline Multivariate OR $(95 \% \mathrm{Cl})^{*}$ & 1.00 & $0.74(0.52$ to 1.06$)$ & 0.63 (0.43 to 0.92$)$ & $0.75(0.52$ to 1.07$)$ & 0.06 \\
\hline Carrots & $\leqslant 3.8$ & $>3.8-14.9$ & $>14.9-24.9$ & $>24.9$ & \\
\hline \multicolumn{6}{|l|}{ Non-smokers } \\
\hline Cases (n) & 337 & 334 & 315 & 305 & \\
\hline Controls (n) & 10002 & 10467 & 10812 & 10811 & \\
\hline Age adjusted OR $(95 \% \mathrm{Cl})$ & 1.00 & $0.95(0.81$ to 1.10$)$ & $0.87(0.74$ to 1.01$)$ & $0.84(0.72$ to 0.98$)$ & 0.01 \\
\hline Multivariate OR $(95 \% \mathrm{Cl})^{*}$ & 1.00 & $0.97(0.83$ to 1.13$)$ & 0.87 (0.74 to 1.02$)$ & 0.81 (0.69 to 0.95$)$ & 0.004 \\
\hline \multicolumn{6}{|l|}{ Ex-smokers } \\
\hline Cases (n) & 153 & 148 & 145 & 138 & \\
\hline Controls ( $\mathrm{n}$ ) & 3606 & 3627 & 3717 & 3758 & \\
\hline Age adjusted OR $(95 \% \mathrm{Cl})$ & 1.00 & 0.97 (0.77 to 1.22 ) & $0.92(0.73$ to 1.16$)$ & $0.86(0.68$ to 1.09$)$ & 0.18 \\
\hline Multivariate OR $(95 \% \mathrm{Cl})^{*}$ & 1.00 & $0.99(0.79$ to 1.25$)$ & $0.93(0.73$ to 1.17$)$ & $0.83(0.66$ to 1.06$)$ & 0.10 \\
\hline \multicolumn{6}{|l|}{ Current smokers } \\
\hline Cases (n) & 76 & 63 & 45 & 45 & \\
\hline Controls (n) & 2360 & 2285 & 1863 & 1775 & \\
\hline Age adjusted OR $(95 \% \mathrm{Cl})$ & 1.00 & $0.85(0.61$ to 1.20$)$ & 0.75 (0.52 to 1.09$)$ & $0.78(0.54$ to 1.14$)$ & 0.13 \\
\hline Multivariate OR $(95 \% \mathrm{Cl})^{*}$ & 1.00 & $0.88(0.63$ to 1.24$)$ & $0.76(0.52$ to 1.11$)$ & $0.78(0.53$ to 1.14$)$ & 0.12 \\
\hline
\end{tabular}

*Adjusted for age, total caloric intake, BMI, physical activity, menopausal status, and vitamin supplementation use.

†Food groups: leafy vegetables (chicory, lettuce and spinach).

associations remained statistically significant; $p$ values of 0.0009 (leafy vegetables), 0.02 (tomatoes) and 0.0003 (carrots) became 0.02, 0.5 and 0.008 , respectively.

We calculated the association between specific vegetable intake and asthma prevalence for non-smokers, ex-smokers, and current smokers because smokers are known to have a lower serum antioxidant level $^{26}$ and higher antioxidant requirements $^{27}$ (table 4). The beneficial effect of leafy vegetable, tomato and carrot intake was slightly stronger in women who reported smoking than in non-smokers, although the small number of asthma cases reporting smoking limited the power of the analysis.

\section{DISCUSSION}

In this large population of women asthma was less frequent in those with a higher intake of leafy vegetables, tomatoes and carrots, and significant dose responses were observed. The effect persisted after adjusting for potential confounding factors. After correction for multiple comparisons, the main result for leafy vegetables and carrots remained statistically significant. This suggests that intake of specific vegetables may play a beneficial role against the prevalence of asthma in our population.

The strengths of our study include the large number of prevalent cases of asthma, a wide variability in dietary intake, ${ }^{28}$ and the use of a validated dietary questionnaire with a very detailed assessment. In addition, the questionnaire has proved useful for evaluating the association between dietary intake and cancer. ${ }^{29}$ However, the cross sectional nature of our analysis limits the interpretation of our results, given that women with asthma might have modified their dietary pattern toward a more "healthy diet" or have avoided some foods because of their symptoms. We do not have information on change of diet over time and therefore cannot assess this. However, it is unlikely that women with asthma symptoms will decrease their intake of tomatoes, carrots, or 
leafy vegetable because of their symptoms, given that these foods are not known to produce allergic reactions. On the other hand, if women increased their intake of these vegetables, this would tend to underestimate the association; our estimates are therefore likely to be conservative. Correction for multiple comparisons using a conservative approach showed that the main result for leafy vegetables and carrots remained statistically significant.

Women who reported using dietary supplements $(\mathrm{n}=14826)$ were on average thinner, were more likely to report allergy, and ate significantly more fruit and vegetables than those who did not report using supplements. However, we did not observe a significant interaction between supplement use and the effect of fruit and vegetable intake on asthma. In addition, in a sub-analysis which included only women who did not report using dietary supplements, the results remained similar. We also evaluated the association of food intake and asthma prevalence stratified by time since the first asthma attack because responses to the dietary questionnaire may be influenced by the most recent food intake. ${ }^{13}$ A similar association was observed for each time period, suggesting that the dietary pattern had been almost constant during adulthood, supporting a potential causal association-for example, for leafy vegetable intake with a 20 year delay since first attack $\left(\mathrm{OR}_{\mathrm{QI}-\mathrm{Q} 4} 0.74,95 \%\right.$ CI 0.61 to 0.90 , test for trend $p=0.003$ ).

Analyses were conducted in detail for fruit and vegetables in relation to hypotheses regarding protection by antioxidants, ${ }^{1}$ and for fish in relation to hypotheses regarding antiinflammatory aspects of omega $3 .^{1}$ We adjusted for total caloric intake and conducted two food models including, in turn, two of the following foods-leafy vegetables, tomatoes, or carrots-but we were not able to adjust for other dietary factors that might be relevant for asthma apart from fish for which we did not find a significant association. ${ }^{8}$ We therefore cannot completely exclude the possibility of confounding by other dietary factors. Although this is a limitation, if confounding is present it should be from dietary factors that exert an even more powerful effect than vegetables. In addition, the decreasing prevalence of asthma with increasing intake of leafy vegetables and carrots provides further evidence for a causal association. We also considered other potential confounding factors, in particular BMI, menopausal status and smoking status. BMI has been related to the frequency of asthma in this ${ }^{30}$ and other populations, ${ }^{31}$ and a diet poor in fruit and vegetables is usually related to a higher BMI. Lack of control for this variable might therefore have biased the association. Similarly, female reproductive hormones are thought to play a role in asthma ${ }^{21-23}$ (although controversy exists) and should be taken into account. Exsmokers had a higher frequency of asthma than those who had never smoked, which is in agreement with other studies showing that, as asthma developed, subjects stopped smoking. ${ }^{32}$ Although our models were adjusted for smoking, there is a possibility for residual confounding by this variable given that smokers are in general more likely to have a diet poor in fruit and vegetables, as observed in our study.

Our definition of asthma was based on one question regarding the occurrence of asthma attacks and the given date of the first attack. Because this information was not confirmed by a physician, we further validated responses with a more detailed questionnaire derived from the ATS questionnaire $^{14}$ and observed a high concordance. Although self-reported asthma in older women may have included chronic obstructive pulmonary disease (COPD), $61.4 \%$ of the cases reported never smoking and are therefore unlikely to have COPD. However, given that we did not measure pulmonary function, we cannot exclude the possibility of COPD in older women, particularly in ex and current smokers. The attributable risk of atopy to asthma is a matter of debate; ${ }^{33}$ asthma may occur without atopy whereas COPD and allergy can occur together. However, the high proportion of women with asthma who reported allergy (76\%) represents an argument in favour of the diagnosis. Some women may have had childhood asthma which, because it remitted and relapsed in adulthood, was classified as adult asthma. These women are likely to report food intake in the same way as women with asthma starting in adulthood. A reporting error, if any, would therefore be random and lead to an underestimation of the association.

One biological mechanism which may be associated with the beneficial effect of vegetable intake on asthma is the effect of antioxidant vitamins ${ }^{18}$ such as carotenoids. Carrots and leafy vegetables are rich in carotenoids $(\alpha$-carotene, $\beta$ carotene, lutein and zeaxanthin) which protect cells from oxidative stress. ${ }^{34}{ }^{35}$ Tomato juice, carrot juice and spinach powder have been shown to increase plasma levels of cystolic glutathione transferase (GST- $\pi$ ), an effect attributed to the upregulation of GST activity by carotenoids. ${ }^{36}$ Carotenoids are known to modulate immune function by enhancing lymphocyte proliferation and cytotoxic T cell activity, and could modulate the production of $\mathrm{PGE}_{2}$ by altering the activation of the arachidonic acid cascade from which $\mathrm{PGE}_{2}$ is derived. In addition, folate-for which leafy vegetables are a major source-has a role in DNA repair and is likely to potentiate the role of antioxidant enzymes. ${ }^{36}$ Smokers are exposed to an extra burden of oxidative stress and have a significantly lower serum level of antioxidants. ${ }^{26}$ It is expected that the protective effect of leafy vegetables and carrots should be greater in women who smoke. This is suggested by our data, but the small number of women in this category limits the power of our analysis.

Our findings on the protective effect of vegetables with a high content of carotenoids are consistent with data from a prospective study of asthma onset among women. ${ }^{7}$ Other studies have reported no association between carotenoid intake and asthma, but most of the studies focused only on $\beta$-carotene intake and did not assess the impact of other carotenoids. ${ }^{18}$ As reported in other studies, we did not observe a protective effect from citrus fruits, ${ }^{4}{ }^{79}{ }^{37}$ foods rich in vitamin $\mathrm{C}$ have been more consistently related to lung function than respiratory symptoms. ${ }^{1}$ Caution is needed, however, when interpreting the results since an infrequent consumption of fruit and vegetables may be an indicator of a poor diet and unhealthy habits. We cannot therefore totally exclude residual confounding by life style.

Fruit and vegetables contain thousands of biologically active phytochemicals, but food composition tables often lack this information and the content of specific nutrients may also be subject to error. Focusing on food intake might be more readily applicable for dietary recommendations and might also enhance our understanding of the relation between phytochemicals and asthma. Public health messages need to be simple and recommendations for food intake are easier to follow than recommended dietary intakes of specific nutrients. This has led to the standard recommendation of five portions of fruit and vegetables a day. ${ }^{10}$ The World Health Organization has recommended a daily intake of at least $400 \mathrm{~g}$ of fruit and vegetables per day, but studies of median fruit and vegetable intake in 10 European countries have shown that a considerable number of consumers failed to meet this target. ${ }^{17}$ In our population, $27 \%$ of the women had a fruit and vegetable intake under $400 \mathrm{~g} /$ day; $65.3 \%$ had an intake of $<200 \mathrm{~g} /$ day leafy, fruity and root vegetables, and $93.4 \%$ had an intake of $<200$ g/day leafy vegetables, tomatoes, and carrots. For the implementation of public health policies, it is important to know which fruit and vegetables might be more likely to prevent specific diseases. 
Our results suggest that a higher intake of leafy vegetables, carrots, and tomatoes may have a beneficial effect against adult asthma. Further studies are needed to confirm these results and to consider the effect of fruit and vegetable intake on the severity of the disease.

\section{Authors' affiliations}

I Romieu, Instituto Nacional de Salud Pública, México

R Varraso, F Kauffmann, INSERM, U780, Villejuif, France

R Varraso, Université Paris 11, Kremlin-Bicêtre, France

V Avenel, F Clavel-Chapelon, INSERM, Equipe Nutrition, Hormones ef Cancer, Institut Gustave Roussy, Villejuif, France

B Leynaert, INSERM, U700, Paris, and Université Paris Diderot, Faculté de Médecine Xavier Bichat, Paris, France

Competing interests: none declared.

\section{REFERENCES}

1 Romieu I, Trenga C. Diet and obstructive lung diseases. Epidemiol Rev 2001;23:268-87.

2 Heffner JE, Repine JE. Pulmonary strategies of antioxidant defense. Am Rev Respir Dis 1989; 140:531-54.

3 Repine JE, Bast A, Lankhorst I. Oxidative stress in chronic obstructive pulmonary disease. Oxidative Stress Study Group. Am J Respir Crit Care Med 1997:156:341-57.

4 Kelly Y, Sacker A, Marmot M. Nutrition and respiratory health in adults: findings from the health survey for Scotland. Eur Respir J 2003;21:664-71.

5 Miedema I, Feskens EJ, Heederik D, et al. Dietary determinants of long-term incidence of chronic nonspecific lung diseases. The Zutphen Study. Am J Epidemiol 1993;138:37-45.

6 Forastiere F, Pistelli R, Sestini P, et al. Consumption of fresh fruit rich in vitamin $C$ and wheezing symptoms in children. SIDRIA Collaborative Group, Italy (Italian Studies on Respiratory Disorders in Children and the Environment). Thorax 2000;55:283-8

7 Troisi RJ, Willett WC, Weiss ST, et al. A prospective study of diet and adultonset asthma. Am J Respir Crit Care Med 1995;151:1401-8.

8 McKeever TM, Britton J. Diet and asthma. Am J Respir Crit Care Med 2004; 170:725-9.

9 Shaheen SO, Sterne JA, Thompson RL, et al. Dietary antioxidants and asthma in adults: population-based case-control study. Am J Respir Crit Care Med 2001;164:1823-8.

10 Potter JD, Finnegan JR, Guinard JX, et al. 5 a day for better health program evaluation report, NIH Publication N0 01-4904. Bethesda, MD: National Cancer Institute, 2000

11 Clavel-Chapelon F, van Liere MJ, Giubout C, et al. E3N, a French cohort study on cancer risk factors. E3N Group. Etude Epidemiologique aupres de femmes de l'Education Nationale. Eur J Cancer Prev 1997;6:473-8.

12 Bertheke PG, de Vente W, Kemper HC, et al. Longitudinal trends in and tracking of energy and nutrient intake over 20 years in a Dutch cohort of men and women between 13 and 33 years of age: the Amsterdam Growth and Health longitudinal study. Br J Nutr 2001;85:375-85.
13 Willett WC Recall of remote diet In: Willett WC ed Nutritional epidemiology. New York: Oxford University Press, 1998: 148-56.

14 Ferris BG. Epidemiology Standardization Project (American Thoracic Society). Am Rev Respir Dis 1978;118:1-120.

15 Lucas F, Niravong M, Villeminot S, et al. Estimation of food portion size using photographs: Relative validity, strengths, weaknesses and recommendations. $J$ Human Nutr Diet 1995;8:65-74.

16 Van Liere MJ, Lucas F, Clavel F, et al. Relative validity and reproducibility of a French dietary history questionnaire. Int J Epidemiol 1997;26:S128-36.

17 Agudo A, Slimani N, Ocke MC, et al. Consumption of vegetables, fruit and other plant foods in the European Prospective Investigation into Cancer and Nutrition (EPIC) cohorts from 10 European countries. Public Health Nutr 2002;5:1179-96.

18 James WO, Schofield EC. Human requirements: a manual for planners and nutritionists. New York: Oxford University Press, 1990.

19 Zar J. Biostatistical analysis, 3rd. ed. Upper Saddle River, NJ: Prentice-Hall, 1996

20 Kleinbaum DG. Logistic regression. New York: Springer, 1994

21 Troisi RJ, Speizer FE, Willett WC, et al. Menopause, postmenopausal estrogen preparations, and the risk of adult-onset asthma. A prospective cohort study. Am J Respir Crit Care Med 1995;152:1183-8.

22 Barr RG, Camargo Jr CA. Hormone replacement therapy and obstructive airway diseases. Treat Respir Med 2004;3:1-7.

23 Barr RG, Wentowski CC, Grodstein F, et al. Prospective study of postmenopausal hormone use and newly diagnosed asthma and chronic obstructive pulmonary disease. Arch Intern Med 2004;164:379-86.

24 Bonferroni CE. Teoria statistica delle classi e calcolo delle probabilità, Pubblicazioni del R Istituto Superiore di Scienze Economiche e Commerciali di Firenze, 1936:3-62.

25 Woodward M. Epidemiology study design and data analysis. Text in statistical science. Florida, USA: Chapman \& Hall/CRC, 1999.

26 Bendich A. Role of antioxidants in the maintenance of immune functions. In: Frei B, ed. Natural antioxidant in human health and disease. New York: Academic Press, 1994:447-467.

27 Institute of Medicine. Dietary reference intakes for vitamin $C$, vitamin $E$, selenium, carotenoids. Washington, DC: National Academy Press, 2000

28 Kesse E, Boutron-Ruault MC, Clavel-Chapelon F. Regional dietary habits of French women born between 1925 and 1950. Eur J Nutr 2004:44:285-92.

29 Miller AB, Altenburg HP, Bueno-de-Mesquita B, et al. Fruits and vegetables and lung cancer: Findings from the European Prospective Investigation into Cancer and Nutrition. Int J Cancer 2004; 108:269-76.

30 Romieu I, Avenel V, Leynaert B, et al. Body mass index, change in body silhouette, and risk of asthma in the E3N cohort study. Am J Epidemiol 2003; 158: 165-74

31 Chinn S. Asthma and obesity: where are we now? Thorax 2003;58:1008-10.

32 Siroux VPI, Oryszczyn MP, Le Moual N, et al. Relationships of active smoking to asthma and asthma severity in the EGEA study. Eur Respir J 2000;15:470-7.

33 Pearce N, Pekkanen J, Beasley R. How much asthma is really attributable to atopy? Thorax 1999;54:268-72.

34 Sies H. Strategies of antioxidant defense. Eur J Biochem 1993;215:213-9.

35 Di Mascio P, Kaiser S, Sies H. Lycopene as the most efficient biological carotenoid singlet oxygen quencher. Arch Biochem Biophys 1989;274:532-8

36 Lindsay DG, Astley SB. European research on the functional effects of dietary antioxidant: EUROFEDA. Mol Aspects Med 2002;23:1-38

37 Soutar A, Seaton A, Brown K. Bronchial reactivity and dietary antioxidants. Thorax 1997;52:166-70.

11 th European Forum on Quality Improvement in Health Care

26-28 April 2006, Prague, Czech Republic

For further information please go to: www.quality.bmjpg.com

Book early to benefit from a discounted delegate rate 